\title{
Eksekusi Aset Debitor yang Berada Di Luar Negeri dalam Penyelesaian Sengketa Kepailitan
}

\author{
Rizka Rahmawati \\ Fakultas Hukum Universitas Udayana, Bali, Indonesia \\ E-mail: rizka.rahmawatii@gmail.com
}

\begin{abstract}
In order to carry out business activities, it is not uncommon for someone to make a debt to have enough capital. These accounts payable activities of course require objects that are a guarantee to give a sense of security to creditors. In its development it is not uncommon for collateral objects to be held by debtors abroad. However, if the collateral object is located abroad, it will not be easy to execute as a debt repayment tool because of the state sovereignty that must be respected and the territoriality principle adopted by a country. The problem in this writing is about how Indonesia's national legal regulation regarding debtors 'assets is located abroad and how efforts can be made so that debtors' assets residing abroad can be executed as debt repayment tools. This research will be conducted using a type of normative juridical research with a type of legislative approach (concept approach) and a conceptual approach. According to the provisions of Article 212 PKPU UUK, that property owned by bankrupt debtors abroad can be used as bankrupt boedel. The provisions of the article give the right to a creditor to obtain repayment by using debtor's assets which are not bound to him which are outside the jurisdiction of the Unitary State of the Republic of Indonesia. In order for collateral objects to be used abroad to be used as a debt repayment tool, a number of ways can be taken, namely by a general court process, bilateral agreements (diplomatic agreements), diplomatic channels, or using the UNCITRAL Law on Cross Model. Border Insolvency with Guide to Enactment.
\end{abstract}

Keywords: Guarantee Objects; Execution; Foreign Affairs.

\section{A. PENDAHULUAN}

Letak aset sebagai salah satu bagian dari bisnis yang dijalankan oleh seseorang saat ini telah mengalami perkembangan. Salah satu perkembangan ini didorong karena nilai investasi yang diletakkan di luar wilayah kewaganegaraannya dianggap dapat mendatangkan keuntungan yang lebih, selain itu tindakan mengembangkan bisnisnya ke negara lain merupakan salah satu wujud dari berhasilnya suatu usaha bersaing di tingkat internasional. Hal ini sejalan dengan konsep portofolio, yang mana investasi terhadap berbagai aset atau berbagai negara diharapkan akan memberikan harapan tingkat return yang lebih tinggi serta manfaat pengurangan risiko yang lebih besar dibandingkan berinvestasi hanya pada pasar dalam negeri (lokal) saja. Perkembangan ini dipermudah dengan adanya teknologi dibidang informasi sehingga transaksi yang dilakukan secara 
lintas batas negara bukan lagi hal yang sulit untuk dilakukan.

Seiring dengan perkembangan perekonomian dunia yang pesat dan akibat dari dampak globalisasi, suatu pelaku usaha baik perseorangan maupun badan hukum dalam melakukan interaksi bisnisnya atau Investasi tidak hanya di dalam suatu wilayah teritorial suatu negara saja, tetapi juga berinteraksi dengan pelaku usaha di negara lain yang memiliki kewarganegaraan yang berbeda (melintasi batas-batas negara) atau dengan kata lain melibatkan unsur asing (foreign element). Kegiatan pelaku usaha yang digambarkan demikian itu termasuk ke dalam "transaksi bisnis internasional". Materi yang diperbincangkan dalam transaksi bisnis internasional esensinya adalah hukum perdata internasional yang terkait dengan kegiatan bisnis. Pelaku usaha yang melakukan transaksi internasional akan terkena beberapa peraturan perundangundangan nasional. Salah satu peraturan perundang-undangan tersebut adalah di bidang kepailitan yang diatur dalam Undang-Undang Nomor 37 Tahun 2004 tentang Kepailitan dan Penundaan Kewajiban Pembayaran Untang (selanjutnya disingkat dengan UUK-PKPU). ${ }^{1}$

Dalam hal mengembangkan bisnis, tidak selalu pelaku usaha memiliki modal yang cukup sehingga hal ini akan mendorong para pelaku bisnis untuk melakukan utang piutang. Proses utang piutang ini akan melibatkan pihak kreditor (yang memberikan piutang) dan pihak debitor (pihak yang memiliki utang). Definisi kreditor dan debitor dapat ditemukan dalam Undang-Undang Nomor 37 Tahun 2004 tentang Kepailitan dan Penundaan Kewajiban Pembayaran Utang, Lembaran Negara Republik Indonesia Tahun 2004 Nomor 131, Tambahan Lembaran Negara Republik Indonesia Nomor 4443 (yang selanjutnya disebut UUK PKPU) dalam Pasal 1 angka 1 dan angka 2.

Setiap kegiatan utang piutang yang dilakukan oleh debitor dan kreditor memerlukan benda yang menjadi jaminan agar apabila suatu hari pihak debitor tidak melakukan prestasinya atau sudah tidak mampu lagi untuk memenuhi prestasinya, maka benda jaminan tersebut yang digunakan oleh kreditor agar haknya untuk mendapatkan pelunasan tetap dapat terpenuhi. Pada umumnya yang digunakan sebagai benda jaminan yakni berupa emas, tanah, kendaraan bermotor, maupun benda lain yang bergerak maupun tidak bergerak ataupun benda yang berwujud dan tidak berwujud yang memiliki nilai (dapat dinilai dengan uang). Terjadi perkembangan dari wujud benda jaminan yang mulai dikenal oleh masyarakat yaitu obligasi, merek, deposito, dan juga saham.

Jaminan merupakan aset pihak peminjam yang dijanjikan kepada pemberi jaminan jika peminjam tidak dapat mengembalikan pinjaman tersebut. ${ }^{2}$ Selain mengenai jaminan, dalam proses utang piutang tentu juga memperjanjikan mengenai jangka waktu pengembalian utang serta besar cicilan yang harus dibayarkan oleh debitor beserta besarnya bunga yang akan dibebankan. Apabila dalam waktu yang diperjanjikan pihak debitor tidak dapat memenuhi prestasinya, maka pihak kreditor memiliki hak untuk menagih sisa utang tersebut. Jika pihak debitor merasa sudah tidak mampu membayar sisa utang yang dimiliki, maka baik pihak debitor dan pihak kreditor dapat mengajukan pihak debitor agar dinyatakan pailit oleh hakim pengadilan niaga. Pailit adalah suatu keadaan di mana debitor tidak mampu untuk melakukan pembayaran-pembayaran terhadap utang-utang kreditornya. ${ }^{3}$

1 Juwana, Hikmahanto. (2001), Transaksi Bisnis Internasional dalam Kaitannya dengan Peradilan Niaga, dimuat dalam Majalah Hukum dan Pembangunan edisi Juli-September 2001, Nomor 3 tahun XXXI, hlm. 224, seperti yang dikutip dalam buku Hikmah, Mutiara. (2007), Aspek-Aspek Hukum Perdata Internasional dalam Perkara-Perkara Kepailitan, Jakarta: Refika Aditama, h. 6.

2 Wikipedia. (2018). Jaminan. Retrieved from: https://id.wikipedia.org/wiki/Jaminan.

3 Hikmah, Mutiara. (2007). Aspek-Aspek Hukum Perdata Internasional dalam Perkara-Perkara 
Setelah debitor dinyatakan pailit, maka selanjutnya akan dilaksanakan proses kepailitan. Hukum kepailitan merupakan produk hukum yang dibuat untuk memberikan jalan keluar bagi seorang debitor yang mengalami kesulitan keuangan (financial distress) agar tidak terus menerus ditagih membayar oleh kreditornya, dan pada saat yang bersama akan memberikan akses kepada kreditor untuk dapat menguasai aset-aset debitornya yang tersisa sebagai pelunasan utangnya meskipun tidak penuh terlunasi. ${ }^{4}$ Tujuan utama dilakukannya kepailitan adalah untuk membagi harta debitor kepada para kreditornya yang dilakukan oleh kurator setelah adanya putusan pailit. ${ }^{5}$ Upaya yang dapat dilakukan kreditor untuk memperoleh kembali piutangnya, dapat dilakukan melalui proses kepailitan dengan menggunakan upaya paksa badan dalam penyelesaian putusan kepailitan yang dikeluarkan oleh pengadilan niaga. ${ }^{6}$ Sesuai dengan definisi kepailitan dalam Pasal 1 angka 1 UUK PKPU bahwa kepailitan adalah sita umum atas semua kekayaan debitor pailit yang pengurusannya dan pemberesannya dilakukan oleh kurator di bawah pengawasan hakim pengawas. Seorang debitor hanya akan dapat dikatakan pailit apabila ia telah diputus pailit oleh pengadilan niaga. ${ }^{7}$ Akibat hukum dari seorang dinyatakan pailit yakni harta kekayaan debitor diletakkan di bawah sita umum (automatic stay) yang menyebabkan debitor tidak dapat menguasai harta kekayaannya. ${ }^{8}$

Apabila melihat definisi dari kepailitan dalam UUK PKPU, maka dimungkinkan proses pemberesan harta debitor pailit akan meliputi aset debitor yang berada di luar yurisdiksi di mana putusan pailit diucapkan. Namun terhadap putusan pailit yang diputus oleh hakim pengadilan niaga Indonesia tidak memiliki kekuatan hukum yang kuat sebagai dasar pengambilan aset di negara lain mengingat adanya perbedaan sistem hukum negara yang mempengaruhi asas yang dianut serta kedaulatan negara yang harus di hormati.

Seperti Indonesia yang menganut asas teritorial sesuai dalam Pasal 436 Reglement op de Burgerlijke Rechtvordering (B.Rv.) yang mana putusan hakim asing tidak dapat diberlakukan secara langsung di wilayah Negara Kesatuan Republik Indonesia, sehingga memiliki akibat hukum terhadap putusan pengadilan Indonesia tidak memiliki kekuatan hukum di negara lain. Larangan melaksanakan putusan asing di wilayah Republik Indonesia muncul karena dianggap sebagai suatu pelanggaran terhadap asas kedaulatan dari negara Republik Indonesia sebagai negara yang merdeka dan berdaulat. Diberlakukannya pasal tersebut dalam sistem hukum Indonesia, tentu akan memberikan konsekuensi tersendiri terhadap kekuatan hukum dari putusan hakim asing. Pasal tersebut telah mencerminkan bahwa Indonesia sendiri menganut asas teritorial yang mengakibatkan putusan asing tidak langsung memiliki kekuatan hukum di wilayah hukum Indonesia, dan sebaliknya putusan hakim Indonesia tidak juga memiliki kekuatan hukum di negara lain. Keadaan ini dapat menimbulkan masalah tersendiri, mengingat

Kepailitan. Jakarta: Refika Aditama, h. 26.

4 Retnaningsih, S. (2018). PERLINDUNGAN HUKUM TERHADAP DEBITOR PAILIT INDIVIDU DALAM PENYELESAIAN PERKARA KEPAILITAN DI INDONESIA. Jurnal Hukum Acara Perdata ADHAPER, 3(1), 1-16, h. 2.

5 Kartoningrat, R. B., \& Andayani, I. (2018). Mediasi Sebagai Alternatif dalam Pengurusan dan Pemberesan Harta Pailit oleh Kurator Kepailitan. Halu Oleo Law Review, 2(1), 291-305, h. 298.

6 Sihotang, E. G., Atmadja, I. B. P., \& Sukihana, I. A. DASAR PERTIMBANGAN HAKIM DAN UPAYA HUKUM DEBITOR PAILIT TERKAIT PENGGUNAAN PAKSA BADAN DALAM KEPAILITAN, h. 5.

7 Makmur, S. (2018). Kepastian Hukum Kepailitan Bagi Kreditur dan Debitur Pada Pengadilan Niaga Indonesia. Mizan: Journal of Islamic Law, 4(2), h. 338.

8 Assalmani, M., \& Priyono, D. (2018). KONSEP PENGATURAN CROSS-BORDER INSOLVENCY BADAN USAHA DI ASSOCIATION OF SOUTHEAST ASIAN NATIONS (ASEAN) DALAM RANGKA MEWUJUDKAN ASEAN ECONOMIC INTEGRATION (Doctoral dissertation, Fakultas Hukum), h. 1. 
tidak jarang harta yang dimiliki debitor pailit berada di luar negeri.

Apabila suatu perkara melibatkan beberapa hukum negara, dimungkinkan perkara tersebut termasuk dalam kategori perkara hukum perdata internasional. Suatu perkara, khusunya perkara kepailitan lintas batas dapat dikategorikan sebagai perkara hukum perdata internasional apabila mengandung foreign elements (unsur asing). Foreign elements merupakan titik-titik pertautan (contacts) dengan satu atau lebih sistem hukum lain di luar sistem hukum negara 'forum' (negara tempat pengadilan yang mengadili perkara), dan pertautan itu sebenarnya ada di dalam fakta-fakta dari perkara. ${ }^{9}$ Terhadap suatu perkara yang termasuk dalam lingkup hukum perdata internasional yang melibatkan sistem hukum yang berbeda serta dibatasi dengan kedaulatan suatu negara, maka akan memunculkan kesulitan dalam penyelesaiannya karena dalam penyelesaian perkara tersebut tetap harus memikirkan kepentingan negara serta keadilan bagi para pihak yang terlibat. Maka berdasarkan uraian tersebut dapat dirumuskan masalah yakni, mengenai bagaimana pengaturan hukum nasional Indonesia mengenai aset debitor yang berada di luar negeri serta bagaimana upaya yang dapat dilakukan agar aset debitor yang berada di luar negeri dapat dieksekusi sebagai alat pelunasan utang

\section{B. METODE PENELITIAN}

Penelitian ini akan dilakukan menggunakan jenis penelitian yuridis normatif, yang artinya penelitian yang dilakukan dengan meneliti bahan kepustakaan yang ada seperti peraturan perundang-undangan, buku-buku yang berkaitan, serta kamus atau ensiklopedi. ${ }^{10}$ Pendekatan ini dilakukan dengan maksud agar peneliti mendapatkan informasi dari berbagai aspek mengenai isu yang sedang dicoba untuk dicari jawabannya. Dari beberapa pendekatan yang ada, dalam penelitian ini jenis pendekatan yang akan digunakan adalah pendekatan perundang-undangan (statue approach) dan pendekatan konseptual (conceptual approach). Dalam melakukan penelitian ini menggunakan 3 (tiga) sumber bahan hukum yaitu, bahan hukum primer, bahan hukum sekunder, dan bahan hukum tersier. Sumber bahan hukum primer merupakan bahan hukum yang sifatnya mengikat seperti peraturan perundang-undangan. Adapun sumber bahan hukum primer pada penelitian ini meliputi: Kitab Undang-Undang Hukum Perdata; dan UndangUndang Nomor 37 Tahun 2004 tentang Kepailitan dan Penundaan Kewajiban Pembayaran Utang, Lembaran Negara Republik Indonesia Tahun 2004 Nomor 131, Tambahan Lembaran Negara Republik Indonesia Nomor 4443. Sedangkan bahan hukum sekunder merupakan bahan hukum pendukung dari bahan hukum primer seperti, bukubuku, hasil karya ilmiah, artikel internet maupun pendapat para ahli yang berakitan dengan eksekusi aset debitor yang berada di luar negeri dalam penyelesaian kepailitan. Serta bahan hukum tersier yang merupakan bahan yang dapat memberikan petunjuk dan/atau penjelasan mengenai bahan hukum primer dan juga bahan hukum sekunder seperti, kamus hukum dan juga ensiklopedia. Adapun teknik pengumpulan bahan hukum yang digunakan dalam penelitian ini dengan melakukan pencatatan secara sistematis dari bahan-bahan yang mendukung mengenai eksekusi aset debitor yang berada di luar negeri dalam penyelesaian kepailitan yang diperoleh melalui studi kepustakaan. Adapun teknik analisis bahan hukum yang digunakan adalah deskripsi, sistematisasi, interprestasi, dan argumentasi.

9 Hardjowahono, Bayu Seto 2013, Dasar-Dasar Hukum Perdata Internasional (Buku Kesatu Edisi Kelima), Penerbit PT Citra Aditya Bakti, Bandung, h. 3.

10 Soekanto, S. \& Mamudji. S. (2009). Penelitian Hukum Normatif Suatu Tinjauan Singkat. Jakarta: RajaGrafindo Persada, h. 13-14. 


\section{PEMBAHASAN}

\section{Pengaturan Hukum Nasional Indonesia Mengenai Aset Debitor yang Berada Di Luar Negeri}

Sebagaimana kita ketahui bersama bahwa ketentuan perundang-undangan yang mengatur tentang kepailitan selaku hukum positif yang berlaku di Indonesia telah mengalami beberapa kali pergantian mulai dari (i). Undang-Undang tentang Kepailitan (Faillissements-verordening, Staatsblad 1905 : 217 juncto Staatsblad 1906 : 348) (ii). Peraturan Pemerintah Pengganti Undang-Undang Nomor 1 Tahun 1998 tentang perubahan atas Undang-Undang tentang Kepailitan, yang kemudian ditetapkan menjadi undang-undang berdasarkan Undang-Undang Nomor 4 Tahun 1998 (iii). Undang-Undang No. 37 Tahun 2004 Tentang Kepailitan dan Penundaan Kewajiban Pembayaran Utang.

Apabila melihat definisi kepailitan dalam ketentuan Pasal 1 angka 1 UUK PKPU, kepailitan merupakan sita umum terhadap seluruh harta yang dimiliki oleh debitor pailit (boedel pailit). Saat seluruh harta debitor pailit berada di bawah sita umum, maka seluruh harta debitor pailit tersebut akan digunakan untuk pelunasan piutang seluruh kreditor (tidak bisa hanya untuk kreditor tertentu). Dengan kata lain, harta debitor pailit yang sudah berada di bawah sita umum tidak dapat lagi dikenai sita khusus oleh penggugat yang memohon diletakkannya sita jaminan atau sita eksekusi.

Lembaga kepailitan merupakan suatu sistem yang mengatur bagimanakah hukum harus bertindak manakala seorang debitor tidak dapat membayar hutang-hutangnya, dan bagaimanakah pertanggungjawaban debitor tersebut, dalam hubungannya dengan harta kekayaan yang masih atau akan dimilikinya. Dilakukan penyitaan secara massal dimaksudkan untuk menghindari para kreditor bertindak sendiri-sendiri, agar semua kreditor memperoleh manfaat dari harta kekayaan debitor pailit, dengan cara dibagi menurut perimbangan hak tagihan atau tuntutan mereka masing-masing.

Lembaga kepailitan merupakan wujud dari pelaksanaan ketentuan pasal 1131 jo 1132 KUH Perdata. Dalam Pasal 1131 KUH Perdata ditentukan bahwa semua harta kekayaan debitor baik benda bergerak atau tidak bergerak, baik yang sekarang maupun yang akan diperolehnya menjadi tanggungan atas perikatan-perikatan pribadinya. Sedangkan Pasal 1132 KUH Perdata menentukan bahwa benda-benda dimaksud sebagai jaminan bagi para kreditor secara bersama-sama hasil penjualan benda-benda tersebut dibagi antara kreditor bersama-sama menurut perbandingan atau imbangan tagihantagihan mereka, kecuali diantara para kreditor tersebut terdapat alasan-alasan untuk diistimewakan (didahulukan) secara sah menurut hokum

Harta kekayaan debitor yang masuk harta pailit merupakan sitaan umum (public attachment, gerechtelijek beslag) beserta apa yang diperoleh selama kepailitan. Definisi tersebut sesuai dengan apa yang ditentukan dalam Pasal 21 UUK PKPU, yang termasuk dalam kategori boedel pailit atau harta kekayaan seseorang yang telah dinyatakan pailit adalah seluruh kekayaan debitor pada saat putusan pernyatan pailit diucapkan serta segala sesuatu yang diperoleh selama kepailitan. Pasal ini sejalan dengan ketentuan Pasal 1131 KUHP yang pada intinya akan mengikat segala bentuk kebendaan yang dimiliki oleh si berhutang, yang mana benda tersebut termasuk benda bergerak ataupun benda tak bergerak, baik benda tersebut sudah ada ataupun yang akan ada kemudian hari. Dalam penentuan pasal tersebut tidak menentukan di mana kedudukan benda yang dimiliki oleh debitor, baik di dalam yurisdiksi negaranya maupun di luar yurisdiksinya. 
Pengaturan dalam Pasal 21 UUK PKPU tidak mengatur dengan jelas mengenai wilayah keberlakuan dari status sita umum terhadap aset debitor pailit tersebut berlaku, begitu juga dalam bagian penjelasannya. Ketentuan dalam pasal tersebut hanya mengatur mengenai kepailitan akan meliputi dari keseluruhan kekayaan yang dimiliki oleh debitor pailit pada saat putusan pailit diucapkan serta segala sesuatu yang diperoleh selama proses kepailitan. Penerapan asas universal dalam hukum kepailitan yang berlaku di Indonesia tercermin dalam ketentuan Pasal 212 sampai dengan Pasal 214 UUK PKPU. Pasal tersebut menunjukkan bahwa wilayah keberlakuan sita umum terhadap harta pailit yang akan diurus dan dibereskan oleh kurator untuk kepentingan kreditor konkuren debitor pailit berdasarkan Pasal 1132 KUHPdt tidak terbatas hanya terhadap harta debitor yang berada di dalam wilayah hukum Indonesia saja akan tetapi juga termasuk harta debitor pailit yang berada di luar negeri. Kitab Undang-Undang Hukum Perdata (yang selanjutnya disebut KUHPdt) dalam Pasal 1131 menentukan bahwa, "Segala kebendaan si berutang, baik yang bergerak maupun yang tak bergerak, baik yang sudah ada maupun yang baru akan ada di kemudian hari, menjadi tanggungan untuk segala perikatan perseorangan". Ketentuan pasal tersebut menunjukkan bahwa piutang kreditor menindih pada seluruh harta debitor tanpa kecuali. Pasal tersebut juga menunjukkan bahwa segala bentuk harta yang dimiliki seseorang dapat dijadikan jaminan, sehingga bagi debitor dalam hal memberikan jaminan kepada kreditor dapat berupa barang bergerak maupun barang tidak bergerak, yang ada ataupun yang akan ada dikemudian hari.

Putusan pernyataan pailit harus dilakukan oleh Pengadilan (Hakim) yang berwenang untuk menjatuhkan pernyataan pailit (sekarang hakim Pengadilan Niaga). Oleh karena itulah hukum kepailitan memiliki karakter sebagai hukum publik bukan hukum privat. Walaupun kepailitan berawal dari Pasal 1131 KUH Perdata, tidaklah berarti bahwa ketentuan hukum kepailitan memiliki sifat sebagai hukum privat. Sebab ketentuan Pasal 1131 KUH Perdata, sekalipun harus diakui merupakan ketentuan hukum perdata, sesuai doktrin karena merupakan bagian dari buku kedua Kitab Undang-Undang Hukum Perdata merupakan ketentuan yang bersifat memaksa (baca: publik) dan tidak dapat disimpangi, sekalipun atas kesepakatan para pihak. ${ }^{11}$

Berdasarkan ketentuan dalam Pasal 212 UUK PKPU, ditentukan bahwa harta benda yang dimiliki oleh debitor pailit yang berada di luar negeri dapat dijadikan sebagai boedel pailit. Pasal tersebut memberikan hak kepada seorang kreditor untuk mendapatkan pelunasan dengan menggunakan harta debitor yang tidak diperikatkan kepadanya yang berada di luar yurisdiksi Negara Kesatuan Republik Indonesia. Apabila merujuk kepada ketentuan pasal tersebut, apabila seorang kreditor mengetahui dan dapat membuktikan bahwa debitornya memiliki harta benda yang berada di luar negeri maka ia bisa mengajukan ke pengadilan agar dapat menuntut benda tersebut sebagai pelunasan piutangnya. Selain dalam ketentuan Pasal 212, mengenai boedel pailit yang berada di luar negeri juga diatur dalam ketentuan Pasal 213 ayat (1). Pada intinya dijelaskan dalam pasal ini bahwa kewajiban untuk mengganti terhadap harta pailit yakni sebesar pelunasan yang diperoleh kreditor penerima peralihan piutang atas harta debitor pailit yang berada di luar negeri. Ditentukan lebih lanjut dalam Pasal 214 ayat (1) yang menentukan bahwa kewajiban mengganti kepada harta pailit adalah sebesar pelunasan yang diperoleh kreditor penerima peralihan piutang atas harta pailit di luar negeri

11 Setiawan. (1998), "Kepailitan Konsep-Konsep Dasar Serta Pengertiannya”, Kumpulan Makalah Calon Hakim Pengadilan Niaga, Mahkamah Agung RI, Jakarta, h. 59. 


\section{Upaya Hukum yang Dapat Dilakukan Agar Aset Debitor yang Berada Di Luar Negeri Dapat Dieksekusi Sebagai Alat Pelunasan Utang}

Seiring dengan perkembangan transaksi bisnis internasional, sengketa kepailitan kini tak lagi terbatas wilayah Negara, dalam kondisi-kondisi tertentu, sengketa kepailitan juga bisa lintas wilayah negara atau dikenal dengan istilah Crossborder Insolvency. Hal ini dapat menimbulkan kompleksitas hukum antara lain terkait penanganan aset pailit yang berada di luar negeri, maka ketentuan-ketentuan dalam Hukum Perdata Internasional menjadi rujukan utama. Di ranah Hukum Perdata Internasional dikenal prinsip universal dan prinsip teritorial. Permasalahan aset pailit yang berada di luar negeri dapat dikaji dengan dua prinsip tersebut.

Berdasarkan prinsip universal, maka putusan pernyataan pailit mengikat seluruh aset debitor, baik di dalam maupun di luar wilayah Indonesia. Sedangkan berdasarkan prinsip teritorial, putusan pernyataan pailit hanya hanya menimbulkan konsekuensi hukum di wilayah hukum putusan tersebut dijatuhkan.

Lazimnya, prinsip teritorial dianut oleh negara-negara Eropa kontinental seperti Belanda dan Perancis termasuk negara jajahannya. Sebagai bekas negara jajahan Belanda, Indonesia sebenarnya juga menganut prinsip teritorial sebagaimana tertuang dalam Pasal 436 Reglement op de Burgerlijke Rechtsvordering yang menegaskan bahwa putusan pengadilan asing tidak dapat dieksekusi di Indonesia.

Namun, jika kita merujuk pada UU Nomor 37 Tahun 2004 tentang Kepailitan dan Penundaan Kewajiban Pembayaran Utang (UU Kepailitan), implisit sebenarnya terbuka 'celah' untuk penyitaan aset pailit yang berada di luar negeri. Pasal 21 menyatakan "Kepailitan meliputi seluruh kekayaan debitor pada saat putusan pernyataan pailit diucapkan serta segala sesuatu yang diperolehnya selama kepailitan". Celah dimaksud terletak pada frasa "seluruh kekayaan debitor" yang dapat diartikan meliputi harta atau aset debitor baik di dalam maupun di luar wilayah Indonesia. Pasal 212, 213, dan 214 UU Kepailitan juga menyiratkan bahwa hukum kepailitan nasional juga dapat menjangkau aset debitor di luar negeri. Pasal 212 mengatur tentang tindakan kreditor pasca putusan pailit untuk mengambil pelunasan seluruh atau sebagian piutangnya dari benda yang termasuk harta pailit yang terletak di luar wilayah Indonesia.

Pasal 213 mengatur tentang tindakan kreditor yang mengalihkan seluruh atau sebagian piutangnya kepada pihak ketiga dengan maksud supaya pihak ketiga mengambil pelunasan atas seluruh atau sebagian dari harta pailit yang berada di luar wilayah Indonesia. Pasal 214 mengatur tentang tindakan setiap orang yang mengalihkan seluruh atau sebagian piutang atau utangnya kepada pihak ketiga sehingga terjadi perjumpaan utang di luar wilayah Indonesia.

Terkait penerapan dua prinsip dalam Hukum Perdata Internasional, pengejaran aset pailit yang berada di negara penganut prinsip teritorial akan menemui kendala karena negara tersebut tidak mengakui putusan pengadilan asing. Namun begitu, kurator sebenarnya bisa melakukan relitigasi di negara dimana aset tersebut berada dengan membawa salinan putusan pailit dari pengadilan Indonesia sebagai bukti otentik.

Sebaliknya, jika negara dimana aset itu berada menganut prinsip universal, pengejaran aset pailit relatif lebih mudah karena negara tersebut mengakui putusan pengadilan asing. Namun yang perlu diingat, dalam konteks hubungan internasional berlaku asas reciprocity, dimana perlakuan suatu negara terhadap negara lain akan dibalas dengan perlakuan yang sama. 
Dalam kasus kepailitan terhadap benda tidak bergerak yang terletak di luar negeri, berdasarkan HPI akan berlaku pilihan hukum dan pilihan forum yang sebelumnya telah ditentukan oleh para pihak dalam suatu perjanjian utang piutangnya yang menentukan mengenai pilihak hukum (choice of law), pilihan forum (choice of jurisdiction), dan pilihan domisili (choice of domicile) apabila pilihan hukum terhadap penyelesaian sengketa tidak diperjanjikan. ${ }^{12}$ Terhadap kasus kepailitan yang sebelumnya sudah dilakukan perjanjian mengenai penyelesaian sengketa tidak akan sulit, karena para pihak sudah sepakat atas hukum mana yang akan berlaku terhadap kasus kepailitan tersebut. Lain halnya terhadap kasus kepailitan yang sebelumnya tidak dilakukan perjanjian penyelesaian sengekata, apabila suatu hari terjadi permasalahan dalam utang piutang tersebut maka akan sulit hukum mana yang akan diberlakukan.

Penyelesaian kasus kepailitan lintas batas negara yang sebelumnya tidak dibuatkan perjanjian utang piutang yang meliputi penyelesaian sengketa dapat dilakukan dengan beberapa cara, yakni mengikuti proses pengadilan secara umum, menggunakan bilateral agreement (perjanjian bilateral), melalui diplomatic channel (hubungan diplomatik), atau menggunakan UNCITRAL Model Law on Cross Border Insolvency with Guide to Enactment. Apabila melalui pengadilan secara umum, maka suatu negara harus mengajukan putusan kepailitan yang diputus oleh negara ke negara di mana boedel pailit berada dan mengkuti segala proses yang terkesan lebih rumit apabila dalam kasus kepailitan lintas batas tersebut melibatkan negara yang memiliki sistem hukum yang berbeda. Mengenai permohonan pengakuan putusan pailit, apabila suatu negara asing mengeluarkan putusan pailit dan diketahui debitor memiliki aset yang berada di Indonesia, maka terhadap putusan asing tersebut dapat dimohonkan agar diakui dan dapat digunakan sebagai dasar pengambilan aset tersebut melalui pengadilan negeri. Hal ini juga berlaku di negara lain seperti di Inggris, yang mana terhadap benda tidak bergerak berlaku hukum Inggris, maka apabila dalam kepailitan terdapat aset yang berada di negaranya dapat digunakan sebagai boedel pailit asalkan negara tersebut bersedia mengajukan permohonan pengakuan putusan melalui wakil yang ditunjuk oleh negaranya dan mengikuti hukum serta prosedur yang berlaku di Inggris. Namun tidak selamanya pengajuan permohonan pengakuan putusan pailit suatu negara asing melalui pengadilan dapat dikabulkan oleh hakim pengadilan di negara yang diajukan permohonan.

Terhadap kasus kepailitan lintas batas negara yang memiliki perjanjian bilateral khususnya mengenai penyelesaian sengketa kepailitan, maka dalam proses penyelesaiannya akan lebih mudah karena dapat menggunakan perjanjian tersebut sebagai dasar. Perjanjian bilateral mengenai kepailitan lintas batas yang biasanya meliputi prinsip umum kerja sama dan koordinasi, mengenai penanganan sengketa tertentu seperti penangguhan, prosedur penyelesaian klaim, dan prosedur komunikasi antar pengadilan. Di dalam UNCITRAL Model Law on Cross Border Insolvency with Guide to Enactment terdapat ketentuan mengenai perjanjian kerja sama antar negara mengenai kepailitan lintas batas. Perjanjian kepailitan dimaksudkan untuk memiliki efek mengikat bagi para pihak ataupun hanya untuk membentuk kerangka kerja sama yang tidak dimaksudkan untuk berkekuatan hukum tetap atau memaksakan kewajiban bagi para pihak. Perjanjian kepailitan juga dapat memasukkan berbagai ketentuan diantaranya dapat menunjukkan maksud untuk memiliki kekuatan hukum dan mengikat para pihak dan beberapa yang lain mungkin saja hanya berbentuk pernyataan itikad baik (good faith).

Pengamanan di dalam perjanjian kepailitan lintas negara terbagi atas dua, yaitu

12 Fuady, M. (2002). Penyelesaian Sengketa Bisnis Melalui Arbitrase. Jurnal Hukum Bisnis, Yayasan Pengembangan Hukum Bisnis, Jakarta, 21, h. 88. 
ketentuan pengamanan yang harus selalu dicantumkan di dalam perjanjian dan ketentuan pengamanan yang dapat dicantumkan di dalam perjanjian. Ketentuan pengamanan yang harus dicantumkan berkaitan dengan kepastian bahwa tidak ada pengurangan/derogasi dari otoritas pengadilan dan kebijakan publik. Sementara ketentuan pengamanan yang dapat dicantumkan terkait keterbukaan terhadap pihak-pihak yang berkepentingan, perlindungan hak pihak ketiga yang tidak menandatangani perjanjian dan kemampuan untuk mengembalikan kepada pengadilan jika terjadi persengketaan.

Tidak semua negara memiliki perjanjian bilateral mengenai penyelesaian sengketa kepailitan, sehingga terdapat cara lain untuk menyelesaikan kasus kepailitan lintas batas yakni melalui hubungan diplomatik (diplomatic channel). Hubungan diplomatik telah digunakan secara umum bersamaan dengan berkembangnya hukum ekonomi internasional. Perkembangan ini diikuti dengan prinsip hukum internasional yang lebih mengarah pada kerja sama dibandingkan dengan sikap kompetisi dan saling bertentangan, seperti Utilization of the space environment for the benefit and in the interests of all countries and the province of all mankind principles dan the proposal for a common heritage of mankind (CHM) principle.

Prinsip demikian merupakan dasar kerja sama internasional yang mengarahkan negara-negara pada perilaku saling mendukung pemecahan masalah ekonomi dan perdagangan termasuk penyelesaian sengketa. Sejalan dengan kelahiran prinsip tersebut maka hubungan diplomatik merupakan saluran yang umum digunakan dalam sengketa perdata termasuk juga dalam penyelesaian kasus kepailitan lintas batas negara. Saat ini telah tercatat bahwa Indonesia menjalin hubungan diplomatik dengan 31 negara besar dunia seperti India, Jepang, Pakistan, Republik Rakyat Tiongkok, Korea Selatan, Timor Leste, Turki, Palestina, Israel, Australia, Papua Nugini, Bulgaria, Denmark, Perancis, Finland, Jerman, Yunani, Tahta Suci, Belanda, Portugal, Rumania, Rusia, Ukraina, Britania Raya, Kanada, Meksiko, Amerika Serikat, Mesir, Libya, Nigeria, dan Afrika Selatan. ${ }^{13}$ Banyaknya negara yang menjalin hubungan diplomatik dengan Indonesia, tentu akan memberikan kemudahan bagi Indonesia dengan negara-negara tersebut untuk menyelesaikan suatu sengketa. Terhadap sengketa kepailitan lintas batas, hubungan diplomatik yang baik akan mempermudah dalam hal komunikasi antar negara yang dapat mempermudah proses dan eksekusi yang menjadi boedel pailit.

Selain melalui pengakuan putusan pailit melalui pengadilan, perjanjian bilateral mengenai kepailitan lintas batas dan hubungan diplomatik, suatu perkara kepailitan lintas batas juga dapat diselesaikan dengan mengggunakan UNCITRAL Model Law on Cross Border Insolvency with Guide to Enactment bagi negara-negara yang meratifikasi atau bagi negara-negara yang sepakat untuk tunduk pada hukum ini. Model Law ini merupakan suatu terobosan hukum yang mempermudah bagi negara-negara yang terlibat perkara kepailitan lintas batas. Bagi negara yang meratifikasi Model Law ini akan diberikan kemudahan dengan adanya pengaturan kerja sama antar negara, baik dalam hal pengajuan, prosedur hingga pelaksanaan putusan pailit serta diadakannya kerja sama antar pengadilan negara yang berperkara.

Berdasarkan kententuan Bab Kesepuluh Bagian Kelima HIR atau Titel Keempat Bagian Keempat RBG, dapat diketahui bahwa pengertian eksekusi adalah "menjalankan isi putusan" (ten uitvoer legging van vonnissen). Menjalankan isi putusan berarti melaksanakan isi putusan pengadilan yaitu melaksanakan secara paksa isi putusan pengadilan tersebut dengan bantuan kekuatan pihak yang berwenang (misalnya aparat

13 Wikipedia. (2019). Hubungan Luar Negeri Indonesia. Retrieved from: https://id.wikipedia.org/wiki/Hubungan_luar_negeri_Indonesia. 
kepolisian) apabila pihak yang kalah (tereksekusi/tergugat/termohon) tidak mau menjalankan isi putusan secara sukarela (vrijwilling, voluntary). Pada prinsipnya hanya putusan yang telah memperoleh kekuatan hukum tetap (inkracht van gewijsde) yang dapat dilaksanakan, namun tidak demikian halnya dengan putusan pengadilan niaga dalam perkara permohonan kepailitan yang berlaku serta merta dan dapat dilaksanakan walaupun ada upaya hukum terhadapnya (uit voorbaar bijvoorraad) sesuai dengan Pasal 8 ayat (7) UU KPKPU.

Eksekusi putusan pailit terhadap harta debitor yang berada diluar negeri, berarti eksekusi yang dilakukan melewati batas-batas suatu negara (cross border bankruptcy) yakni menjalankan putusan pailit yang melintasi batas-batas suatu negara, sehingga aspek internasional akan muncul/kelihatan karena terdapat harta kekayaan debitor yang berada di dua negara atau lebih. Eksekusi putusan pailit yang dimaksudkan disini tentu mulai dari likuidasi sampai pemberesan kewajiban debitor terhadap kreditor dengan melakukan penjualan seluruh harta pailit melalui penjualan didepan umum/lelang (vide pasal $185 \mathrm{UU}$ KPKPU) yang dilakukan oleh kurator. Sehubungan dengan eksekusi putusan pailit dari suatu pengadilan luar negeri/asing sebagaimana dimaksud di atas, terdapat 2 (dua) prinsip yang diakui secara universal yakni:

1) Prinsip Universalitas (unite universalite exterritorialite de la faillite) yang pada pokoknya mengakui/menganut bahwa suatu putusan pailit yang diucapkan disuatu negara mempunyai akibat hukum dimana saja orang yang dinyatakan pailit mempunyai harta benda.

2) Prinsip Teritorialitas (pluralite de faillites, teritorialite de la failite) yang pada pokoknya mengakui/menganut bahwa suatu putusan pailit hanya mengenai bagian-bagian harta benda debitor yang terletak didalam wilayah negara tempat putusan kepailitan itu di ucapkan.

Sejalan dengan konsep hukum lex spesialis derogat lex generalis sebagaimana dimaksud di atas, Pasal 299 UU KPKPU menentukan bahwa hukum acara yang berlaku dalam kepailitan adalah hukum acara perdata. Tentunya hukum acara perdata yang dimaksudkan disini adalah hukum acara sebagaimana antara lain diatur dalam HIR, RBG dan Rv yang juga berlaku dalam melaksanakan/eksekusi putusan pailit. Sehubungan dengan eksekusi putusan pailit atas harta debitor yang berada di luar negeri, dalam UU KPKPU dapat dilakukan 2 (dua) pengelompokan yakni :

1) Tentang eksekusi putusan pailit pengadilan asing terhadap harta benda debitor yang berada di Indonesia.

Sesuai dengan Pasal 299 UUKPKU yang menentukan bahwa hukum acara yang berlaku dalam kepailitan adalah hukum acara perdata, maka terhadap eksekusi putusan pailit pengadilan asing terhadap harta benda debitor yang berada di Indonesia haruslah berpedoman pada Pasal $436 \mathrm{Rv}$ yang pada pokoknya menentukan bahwa : Kecuali dalam hal-hal yang ditentukan oleh Pasal 724 WVK dan lain-lain perundang-undangan, tidak dapat dilaksanakan keputusankeputusan yang diucapkan oleh hakim-hakim asing atau pengadilan asing di wilayah Republik Indonesia. Sehubungan dengan putusan pengadilan asing, UU KPKPU menganut prinsip teritorialitas yakni putusan pailit pengadilan asing tidak mempunyai kekuatan eksekusi terhadap harta debitor yang berada di Indonesia. Tegasnya putusan pailit pengadilan asing/negara lain sesuai dengan Pasal 436 Rv tidak dapat dilaksanakan/dieksekusi di Indonesia.

2) Tentang putusan pengadilan niaga Indonesia mengenai harta benda debitor yang berada diluar Indonesia. 
Tentang eksekusi putusan pengadilan niaga Indonesia terhadap harta debitor yang berada diluar negeri UU KPKPU telah mengatur dalam Pasal 212 sampai dengan pasal 214, perihal Ketentuan-Ketentuan Hukum Internasional, namun menurut penulis dalam pasal-pasal tersebut sama sekali tidak diatur lebih lanjut secara jelas tentang hukum acara dalam melaksanakan eksekusi putusan pailit tersebut. Berdasarkan Pasal 21 UU KPKPU yang menentukan : Kepailitan meliputi seluruh kekayaan debitor pada saat putusan pernyataan pailit diucapkan serta segala sesuatu yang diperoleh selama kepailitan maka dapat disimpulkan bahwa UU KPKPU sesungguhnya juga menganut prinsip universalitas sebagaimana dimaksud di atas.

Prinsip universalitas yang dianut dalam UU KPKPU ini, dalam praktek sangat sulit untuk dilaksanakan bahkan hampir tidak mungkin untuk dilaksanakan mengingat konsep kedaulatan negara (sovereignty) dimana masing-masing negara mempunyai kedaulatan hukum yang tidak dapat diintervensi oleh negara lain termasuk dalam melaksanakan putusan pengadilan asing/negara lain. Sulitnya pelaksanaan putusan pengadilan niaga Indonesia terhadap harta debitor yang berada diluar negeri mengakibatkan para pelaku usaha menghadapi jalan buntu (deadlock) dalam memperoleh haknya berdasarkan putusan pengadilan niaga.

Hingga saat ini belum ada tersedia perjanjian internasional yang mengatur secara khusus eksekusi/pelaksanaan putusan pailit yang bersifat lintas batas yang dapat diikuti oleh negara manapun secara universal. Pada saat ini baru ada perjanjian internasional bagi putusan kepailitan lintas batas yang berlaku secara regional (regional agrrement) seperti yang berlaku di Masyarakat Ekonomi Eropa. Negara-negara yang tergabung dalam Uni Eropa telah memiliki perjanjian internasional dalam bidang kepailitan yang disebut Convention on Insolvency Proceedings

\section{PE N T T P}

Berdasarkan uraian sebelumnya, maka dapat disimpulkan bahwa berdasarkan ketentuan Pasal 21 UUK PKPU, maka yang termasuk dalam kategori boedel pailit atau harta kekayaan seseorang yang telah dinyatakan pailit adalah seluruh kekayaan debitor pada saat putusan pernyatan pailit diucapkan serta segala sesuatu yang diperoleh selama kepailitan. Ditentukan secara lebih jelas dalam Pasal 212 UUK PKPU, bahwa harta benda yang dimiliki oleh debitor pailit yang berada di luar negeri dapat dijadikan sebagai boedel pailit. Maka berdasarkan ketentuan pasal tersebut memberikan hak kepada seorang kreditor untuk mendapatkan pelunasan dengan menggunakan harta debitor yang tidak diperikatkan kepadanya yang berada di luar yurisdiksi Negara Kesatuan Republik Indonesia. Guna dapat menggunakan benda jaminan debitor yang berada di luar negeri sebagai alat pelunasan utang, maka dapat ditempuh beberapa cara yakni dengan proses pengadilan secara umum, menggunakan bilateral agreement (perjanjian bilateral), melalui diplomatic channel (hubungan diplomatik), atau menggunakan UNCITRAL Model Law on Cross Border Insolvency with Guide to Enactment. 


\section{DAFTAR PUSTAKA}

\section{Buku}

[1] Bayu Seto Hardjowahono, 2013, Dasar-Dasar Hukum Perdata Internasional (Buku Kesatu Edisi Kelima), Penerbit PT Citra Aditya Bakti, Bandung.

[2] Hikmah, Mutiara. (2007). Aspek-Aspek Hukum Perdata Internasional dalam Perkara-Perkara Kepailitan. Jakarta: Refika Aditama.

[3] Soekanto, S. \& Mamudji. S. (2009). Penelitian Hukum Normatif Suatu Tinjauan Singkat. Jakarta: PT RajaGrafindo Persada.

\section{Jurnal dan Lain-Lain}

[4] Assalmani, M., \& Priyono, D. (2018). KONSEP PENGATURAN CROSS-BORDER INSOLVENCY BADAN USAHA DI ASSOCIATION OF SOUTHEAST ASIAN NATIONS (ASEAN) DALAM RANGKA MEWUJUDKAN ASEAN ECONOMIC INTEGRATION (Doctoral dissertation, Fakultas Hukum).

[5] Fuady, M. (2002). Penyelesaian Sengketa Bisnis Melalui Arbitrase. Jurnal Hukum Bisnis, Yayasan Pengembangan Hukum Bisnis, Jakarta, 21.

[6] Kartoningrat, R. B., \& Andayani, I. (2018). Mediasi Sebagai Alternatif dalam Pengurusan dan Pemberesan Harta Pailit oleh Kurator Kepailitan. Halu Oleo Law Review, 2(1), 291-305.

[7] Makmur, S. (2018). Kepastian Hukum Kepailitan Bagi Kreditur dan Debitur Pada Pengadilan Niaga Indonesia. Mizan: Journal of Islamic Law, 4(2).

[8] Retnaningsih, S. (2018). PERLINDUNGAN HUKUM TERHADAP DEBITOR PAILIT INDIVIDU DALAM PENYELESAIAN PERKARA KEPAILITAN DI INDONESIA. Jurnal Hukum Acara Perdata ADHAPER, 3(1), 1-16.

[9] Sihotang, E. G., Atmadja, I. B. P., \& Sukihana, I. A. DASAR PERTIMBANGAN HAKIM DAN UPAYA HUKUM DEBITOR PAILIT TERKAIT PENGGUNAAN PAKSA BADAN DALAM KEPAILITAN.

[10] Setiawan. (1998), "Kepailitan Konsep-Konsep Dasar Serta Pengertiannya", Kumpulan Makalah Calon Hakim Pengadilan Niaga, Jakarta: Mahkamah Agung RI.

[11]Wikipedia. (2018). Jaminan. Retrieved from: https://id.wikipedia.org/wiki/Jaminan.

[12] Wikipedia. (2019). Hubungan Luar Negeri Indonesia. Retrieved from: https://id.wikipedia.org/wiki/Hubungan_luar_negeri_Indonesia. 